\title{
PENGARUH RETURN ON EQUITY (ROE) DAN EARNING PER SHARE (EPS) TERHADAP HARGA SAHAM PADA PERUSAHAAN MANUFAKTUR SUB SEKTOR MAKANAN DAN MINUMAN YANG TERDAFTAR DI BURSA EFEK INDONESIA TAHUN 2015-2019
}

\author{
Mattoasi $^{1}$, Amir Lukum ${ }^{2}$, Nur Hafisah Budi ${ }^{3}$ \\ 1,2,3 Dosen jurusan Akuntansi, Universitas Negeri Gorontalo \\ Email : 'ㄹattoasi@ung.ac.id ${ }^{2}{ }^{2}$ amirlukum@ung.ac.id ${ }^{3}$ ichabudi1999@gmail.com
}

\section{Submitted: \\ $27 / 11 / 2021$ \\ Revised: \\ $05 / 12 / 2021$ \\ Accepted: \\ $25 / 12 / 2021$ \\ Online-Published: \\ $31 / 12 / 2021$}

INFORMASI ARTIKEL

\begin{abstract}
ABSTRAK
Penelitian ini bertujuan untuk mengetahui secara parsial dan simultan pengaruh Return On Equity (ROE) dan Earning Per Share (EPS) terhadap harga saham. Metode penelitian yang digunakan adalah metode penelitian kuantitatif, dimana data yang digunakan berupa data sekunder. Populasi dalam penelitian ini adalah perusahaan manufaktur sub sektor makanan dan minuman yang terdaftar di Bursa Efek Indonesia tahun 2015-2019 yang berjumlah 30 perusahaan. Jumlah sampel yang digunakan sebanyak 20 perusahaan dengan teknik Purposive Sampling. Teknik analisis data yang digunakan pada penelitian ini adalah analisis regresi berganda dengan menggunakan metode data panel. Hasil penelitian secara parsial menunjukkan bahwa Return On Equity (ROE) tidak berpengaruh terhadap harga saham pada perusahaan manufaktur sub sektor makanan dan minuman yang terdaftar di Bursa Efek Indonesia tahun 2015-2019 dan Net Profit Margin (NPM) berpengaruh terhadap harga saham pada perusahaan manufaktur sub sektor makanan dan minuman yang terdaftar di Bursa Efek Indonesia tahun 2015-2019. Sedangkan secara simultan menunjukkan bahwa Return On Equity (ROE) dan Earning Per Share (EPS) secara bersama-sama berpengaruh terhadap harga saham pada perusahaan manufaktur sub sektor makanan dan minuman yang terdaftar di Bursa Efek Indonesia tahun 2015-2019.
\end{abstract}

Kata kunci : Return On Equity (ROE), Earning Per Share (EPS) dan Harga Saham

\begin{abstract}
ABSTRACK
This study aims to determine partially and simultaneously the effect of Return On Equity (ROE) and Earning Per Share (EPS) on stock prices. The research method used is a quantitative research method, where the data used is in the form of secondary data. The population in this study is the food and beverage sub-sector manufacturing companies listed on the Indonesia Stock Exchange in 2015-2019, totaling 30 companies. The number of samples used as many as 20 companies with purposive sampling technique. The data analysis technique used in this research is multiple regression analysis using panel data method. The results of the study partially show that Return On Equity (ROE) has no effect on stock prices in food and beverage sub-sector manufacturing companies listed on the Indonesia Stock Exchange in 2015-2019 and Net Profit Margin (NPM) affects stock prices in sub-sector manufacturing companies. sector. food and beverage sector listed on the Indonesia Stock Exchange in 2015-2019. Meanwhile, it simultaneously shows that Return On Equity (ROE) and Earning Per Share (EPS) together have an effect on stock prices in food and beverage sub-sector manufacturing companies listed on the Indonesia Stock Exchange in 2015-2019.
\end{abstract}

Keywords: Return On Equity (ROE), Earning Per Share (EPS) and Stock Price 


\section{A. PENDAHULUAN}

\section{Latar Belakang}

Masuk dalam perkembangan perekonomian Indonesia, tentunya banyak perusahaan yang melakukan pembesaran atau perluasan usaha yang dapat dilihat dari pesatnya perkembangan perusahaan yang terdaftar di Bursa Efek Indonesia salah satu diantaranya adalah perusahaan manufaktur. Industri Manufaktur ialah industri yang bergerak dibidang industri, manufaktur memiliki peranan yang penting untuk industri tiap negara, ini disebabkan manufaktur mempunyai jumlah industri yang lumayan banyak dibanding dengan industri lain sehingga industri manufaktur bisa menjadi salah satu alternatif utama untuk investor buat menanamkan modal dipasar modal.

Investasi atau pembelian saham pada suatu perusahaan para investor sudah pasti memperhatikan harga saham dalam perusahaan tersebut. Harga saham sangat mempengaruhi keuntungan seorang investor dalam melakukan pembelian saham. Dalam hal ini harga saham dapat mengalami yang namanya fluktuasi atau keadaan yang dimana harga saham memperlihatkan gejala turunnaiknya harga dan tentunya terdapat faktor yang bisa mempengaruhi harga saham.

Ada beberapa sektor yang dianggap sangat penting dalam perekonomian Indonesia, salah satu diantaranya adalah sektor industri barang konsumsi sub sektor makanan dan minuman. Perusahaan makanan dan minuman ini adalah perusahaan yang termasuk dalam perusahaan industri pengolahan yang dimana proses mengolahnya dari bahan baku menjadi barang setengah jadi ataupun menjadi barang jadi. Perusahaan makanan dan minuman dilihat masih menjadi salah satu sektor harapan dalam menopang pertumbuhan perusahaan manufaktur. Dalam penelitian ini mengambil harga saham di perusahaan makanan dan minuman di kerenakan perusahaan makanan dan minumann mengalami fluktuatif harga saham.

Seorang investor dalam menentukan pilihan dapat menggunakan 2 (dua) analisis atau pendekatan yaitu pendekatan teknikal didasarkan pada data (perubahan) harga saham di masa lalu sebagai upaya untuk memperkirakan harga saham di masa yang akan mendatang, sedangkan pendekatan fundamental didasarkan pada informasi yang diterbitkan oleh emiten maupun oleh administrator bursa efek (Abdul, 2005). Analisis fundamental ini sendiri adalah analisis yang sering digunakan. Analisis fundamental ini dapat diperoleh dari laporan keuangan perusahaan yang terdapat dalam laporan tahunan perusahaan yang dilaporkan dalam Bursa Efek Indonesia.

Salah satu hal paling mendasar sebelum investor menginvestasikan modalnya adalah menilai kinerja perusahaan melalui laporan keuangan dengan analisis rasio. Rasio profitabilitas atau disebut juga rasio keuntungan adalah rasio yang digunakan untuk mengukur seberapa besar tingkat keuntungan yang dapat diperoleh oleh perusahaan (Sutrisno, 2017). Salah satu rasio yang digunakan dalam rasio profitabilitas yang sangat penting untuk diperhatikan dalam mengetahui sejauh mana investasi di suatu perusahaan mampu memberikan return yang sesuai dengan apa yang diinginkan oleh investor adalah Return On Equity (ROE) beberapa penelitian yang telah dilakukan sebelum ini berkaitan dengan ROE terhadap harga saham. Hasil penelitian yang dilakukan oleh (Nurlia, 2017) menyatakan bahwa secara parsial ROE tidak berpengaruh terhadap harga saham dan secara simultan ROE berpengaruh terhadap harga saham. Hasil ini sejalan dengan 
penelitian yang dilakukan oleh (Egam et al, 2017) dan (Al Umar dan Savitri, 2020). Akan tetapi berbeda halnya dengan hasil penelitian yang dilakukan oleh (Indrawati et al, 2016) yang menyatakan bahwa secara parsial ROE berpengaruh negatif terhadap harga saham dan secara simultan ROE berpengaruh terhadap harga saham. Hasil ini sejalan dengan penelitian yang dilakukan oleh (Rahmadewi dan Abundanti, 2018). Adapun hasil penelitian yang berbeda dilakukan oleh (Pratama et al, 2019) yang menyatakan bahwa secara parsial dan simultan ROE berpengaruh terhadap harga saham.

Indikator selanjutnya adalah Earning Per Share (EPS) beberapa penelitian yang telah dilakukan sebelum ini berkaitan dengan EPS terhadap harga saham. Hasil penelitian yang dilakukan oleh (Pratama et al, 2019) yang menyatakan bahwa secara parsial dan simultan EPS berpengaruh terhadap harga saham. Hasil ini sejalan dengan penelitian yang dilakukan oleh (Nurlia, 2017), (Egam et al, 2017) dan (Al Umar dan Savitri, 2020). Akan tetapi, berbeda halnya dengan hasil penelitian yang dilakukan oleh (Rahmadewi dan Abundanti, 2018) yang menyatakan secara parsial EPS berpengaruh negatif terhadap harga saham dan secara simultan berpengaruh terhadap harga saham. Adapun hasil penelitian yang dilakukan oleh (Audya et al, 2019) yang menyatakan bahwa secara parsial EPS tidak berpengaruh terhadap harga saham dan secara simultan berpengaruh terhadap harga saham.

Berdasarkan uraian di atas dengan adanya perbedaan hasil penelitian, maka peneliti tertarik untuk melakukan penelitian kembali dengan judul "Pengaruh Return On Equity (ROE) dan Earning Per Share (EPS) terhadap Harga Saham Pada Perusahaan Manufaktur Sub Sektor Makanan dan Minuman Yang
Terdaftar di Bursa Efek Indonesia Tahun 2015-2019"

\section{Rumusan Masalah}

Berdasarkan latar belakang yang telah diuraikan diatas, maka penulis akan menguji tentang faktor-faktor yang mempengaruhi harga saham perusahaan sub sektor makanan dan minuman yang terdaftar di Bursa Efek Indonesia tahun 2015-2019 dengan rumusan masalah sebagai berikut :

1. Apakah Return On Asset (ROA) berpengaruh terhadap harga saham perusahaan manufaktur sub sektor makanan dan minuman yang terdaftar di Bursa Efek Indonesia tahun 2015-2019?

2. Apakah Net Profit Margin (NPM) berpengaruh terhadap harga saham perusahaan manufaktur sub sektor makanan dan minuman yang terdaftar di Bursa Efek Indonesia tahun 2015-2019?

3. Apakah Return On Asset (ROA) dan Net Profit Margin (NPM) berpengaruh terhadap harga saham perusahaan manufaktur sub sektor makanan dan minuman yang terdaftar di Bursa Efek Indonesia tahun 2015-2019?

\section{Tujuan Penelitian}

Adapun tujuan yang ingin dicapai dari penelitian ini adalah sebagai berikut :

1. Untuk mengetahui pengaruh Return On Equity terhadap harga saham perusahaan sub sektor makanan dan minuman yang terdaftar di Bursa Efek Indonesia tahun 2015-2019.

2. Untuk mengetahui pengaruh Earning Per Share terhadap harga saham perusahaan sub sektor makanan dan minuman yang terdaftar di Bursa Efek Indonesia tahun 2015-2019. 
3. Untuk mengetahui pengaruh Return On Equity dan Earning Per Share terhadap harga saham perusahaan sub sektor makanan dan minuman yang terdaftar di Bursa Efek Indonesia tahun 2015-2019.

\section{Kajian Teori}

Penelitian ini berkaitan dengan harga saham. Teori yang digunakan dalam penelitian ini adalah teori sinyal (Signaling Theory) berasal dari pemikiran mengenai istilah Assymetri Information (informasi asimetris) yang merupakan ketidakseimbangan mengenai informasi kualitas produk antara pembeli dan penjual. Ketika pembeli tidak mengetahui informasi mengenai spesifik produk, sehingga pembeli hanya mempunyai presepsi umum mengenai produk tersebut, sehingga pembeli menilai semua produk itu sama, baik produk yang berkualitas tinggi maupun berkualitas rendah, sehingga akan merugikan penjual yang mempunyai produk dengan kualitas tinggi. Kondisi ini disebut Adverse Selection. Adverse Selection dapat dikurangi jika penjual mengkomunikasikan produk mereka dengan memberikan informasi mengenai kualitas produk-produk yang dimiliki (Arkelov, 1970).

Pemikiran Arkelov

tersebut dikembangkan oleh Michael Spence pada tahun 1973 dalam penelitian yang dilakukan olehnya dengan judul J $o b$ Market Signalling. Dalam teori ini melibatkan 2 (dua) pihak, yaitu pihak dalam adalah manajemen yang berperan sebagai pihak yang memberikan sinyal dan pihak luar adalah investor yang berperang sebagai pihak yang menerima sinyal. Spence mengatakan bahwa pihak manajemen berusaha untuk memberikan suatu isyarat atau sinyal berupa informasi yang relevan yang dapat dimanfaatkan oleh pihak investor. Kemudian, pihak investor akan membuat keputusan sesuai dengan pemahamannya terhadap sinyal tersebut. Salah satu penelitian yang menggunakan teori ini dalam penetapan harga saham antara lain penelitian yang dilakukan oleh (Indrawati et al, 2016) dengan penelitian Pengaruh Earning Per Share (EPS), Return On Equity (ROE), Return On Asset (ROA) dan Net Profit Margin (NPM) terhadap harga saham.

Berkaitan dengan harga saham juga telah dilakukan penelitian oleh (Nurlia, 2017) dengan menggunakan variabel Earning Per Share (EPS), Operating Profit Margin (OPM), Net Profit Margin (NPM), Return On Asset (ROA) dan Return On Equity (ROE) terhadap harga saham. Hasil dari penelitiannya menyatakan bahwa secara parsial EPS berpengaruh terhadap harga saham, sedangkan variabel OPM, NPM, ROA dan ROE tidak berpengaruh terhadap harga saham. Secara simultan EPS, OPM, NPM, ROA dan ROE berpengaruh terhadap harga saham.

Tidak jauh berbeda dengan penelitian yang dilakukan oleh (Egam et al, 2017) dengan menggunakan variabel Return On Asset (ROA), Return On Equity (ROE), Net Profit Margin (NPM) dan Earning Per Share (EPS) terhadap harga saham. Hasil dari penelitiannya menyatakan bahwa secara parsial NPM dan EPS berpengaruh terhadap harga saham dan ROA dan ROE tidak berpengaruh terhadap harga saham. Secara simultan ROA, ROE, EPS dan NPM berpengaruh terhadap harga saham.

Mengenai harga saham penelitian yang lain mengenai harg saham juga telah dilakukan oleh (Pratama et al, 2019) dengan menggunakan variabel Return On Equity (ROE), Earning Per Share (EPS), Current Ratio (CR), dan Debt to Equity Ratio (DER) terhadap harga saham. Hasil dari penelitiannya menyatakan bahwa secara parsial ROE dan EPS berpengaruh terhadap harga saham, sedangkan $\mathrm{CR}$ dan DER tidak 
berpengaruh terhadap harga saham. Secara simultan ROE, EPS, DER dan CR berpengaruh terhadap harga saham.

Sehingga peneliti dapat menarik kesimpulan yang dimaksud dengan harga saham adalah harga yang terbentuk karena permintaan dan penawaran yang ada dipasar jual beli saham dan biasanya merupakan harga penutupan. Pada umumnya kinerja sebuah perusahaan akan berpengaruh terhadap harga saham perusahaan tersebut. Semakin baik kinerja suatu perusahaan maka semakin tinggi laba usaha yang akan diperoleh dan pemegang saham turut menikmati keuntungan dari penghasilan perusahaan, sehingga banyak investor yang ingin memiliki saham perusahaan tersebut dan harga saham akan naik.

Sejalan dengan harga saham beberapa variabel yang diduga dapat berpengaruh terhadap harga saham adalah Return On Equity (ROE). Menurut (Sutrisno, 2017) Return On Equity (ROE) yaitu kemampuan perusahaan dalam menghasilkan keuntungan dengan modal sendiri yang dimiliki, sehingga ROE ini ada yang menyebut sebagai rentabilitas modal sendiri. Laba yang diperhitungkan adalah laba bersih setelah dipotong pajak atau EAT. Beberapa penelitian yang berkaitan dengan ROE antara lain penelitian yang dilakukan oleh (Nurlia, 2017) yang menyatakan bahwa secara parsial ROE tidak berpengaruh terhadap harga saham dan secara simultan ROE berpengaruh terhadap harga saham. Penelitian ini sejalan dengan penelitian yang dilakukan oleh (Egam et al, 2017) dan (Al Umar dan Savitri, 2020).

Namun berbeda halnya dengan penelitian yang dilakukan oleh (Indrawati et al, 2016) yang menyatakan bahwa secara parsial ROE berpengaruh negatif terhadap harga saham dan secara simultan ROE berpengaruh terhadap harga saham. Penelitian ini sejalan dengan penelitian yang dilakukan oleh (Rahmadewi dan Abundanti, 2018).
Berbeda juga dengan hasil penelitian yang dilakukan oleh (Pratama et al, 2019) yang menyatakan secara parsial dan simultan ROE berpengaruh terhadap harga saham.

Selain ROE, variabel Earning Per Share (EPS) juga dapat berpengaruh terhadap harga saham. Menurut (Sutrisno, 2017) Earning Per Share atau laba per lembar merupakan ukuran kemampuan perusahaan untuk menghasilkan keuntungan per lembar saham pemilik. Laba yang digunakan sebagai ukuran adalah laba bagi pemilik atau EAT. Beberapa penelitian yang berkaitan dengan EPS antara lain penelitian yang dilakukan oleh (Nurlia, 2017) yang menyatakan bahwa secara parsial dan simultan EPS berpengaruh terhadap harga saham. Hasil penelitian ini sejalan dengan penelitian yang dilakukan oleh (Pratama et al, 2019), (Egam et al, 2017) dan (Al Umar dan Savitri, 2020).

Akan tetapi, berbeda halnya dengan hasil penelitian yang dilakukan oleh (Rahmadewi dan Abundanti, 2018) yang menyatakan secara parsial EPS berpengaruh negatif terhadap harga saham dan secara simultan berpengaruh terhadap harga saham. Adapun hasil penelitian yang dilakukan oleh (Audya et al, 2019) yang menyatakan bahwa secara parsial EPS tidak berpengaruh terhadap harga saham dan secara simultan berpengaruh terhadap harga saham.

\section{Hipotesis}

$\mathrm{H}_{1}$ : Return On Equity (ROE) berpengaruh terhadap harga saham pada perusahaan manufaktur sub sektor makanan dan minuman yang terdaftar di Bursa Efek Indonesia Tahun 2015-2019.

$\mathrm{H}_{2}$ : Earning Per Share (EPS) berpengaruh terhadap harga saham pada perusahaan manufaktur sub sektor makanan dan minuman yang 
terdaftar di Bursa Efek Indonesia Tahun 2015-2019.

$\mathrm{H}_{3}$ : Return On Equity (ROE) dan Earning Per Share (EPS) berpengaruh terhadap harga saham pada perusahaan manufaktur sub sektor makanan dan minuman yang terdaftar di Bursa Efek Indonesia Tahun 2015-2019.

\section{B. METODE PENELITIAN}

\section{Jenis Penelitian}

Penelitian ini merupakan penelitian kuantitaf, dimana menurut (Sugiyono, 2018) metode kuantitatif adalah metode yang berdasar filsafat positivisme bertujuan menggambarkan dan menguji hipotesis yang dibuat peneliti.

\section{Tempat dan Waktu Penelitian}

Penelitian dilakukan di Galeri Investasi Bursa Efek Indonesia (GIBEI) yang berada di Fakultas Ekonomi Universitas Negeri Gorontalo yaitu dengan cara mengunduh data laporan keuangan perusahaan dan data historis pasar masing-masing perusahaan yang terdaftar di Bursa Efek Indonesia dari tahun 2015-2019. Waktu dalam melakukan kegiatan penelitian ini direncanakan akan dimulai dari bulan November 2020 sampai dengan selesai.

\section{Metode Pengumpulan Data}

Adapun metode pengumpulan data yang digunakan dalam penelitian ini adalah data sekunder antara lain :

1. Studi Pustaka, yaitu teknik pengumpulan data dengan cara membaca serta mengkaji semua sumber atau literatur yang didapatkan dari buku, makalah, jurnal serta sumber tertulis lainnya seperti artikel dari media cetak maupun internet yang tentunya berkaitan dengan penelitian yang dilakukan.

2. Dokumentasi, yaitu teknik pengumpulan data yang berupa laporan keuangan tahunan perusahaan manufaktur sub sektor makanan dan minuman periode 2015-2019 di Bursa Efek Indonesia yang dimana sumber tersebut diperoleh dari halaman website www.idx.co.id

\section{Populasi dan Sampel}

Populasi dalam penelitian ini adalah 30 perusahaan manufaktur sub sektor makanan dan minuman yang terdaftar di Bursa Efek Indonesia. Teknik sampel yang digunakan adalah Nonprobability sampling merupakan teknik sampling yang tidak memberikan peluang atau kesempatan yang sama bagi setiap unsur atau anggota populasi untuk dipilih menjadi sample. Teknik nonprobability sampling yang digunakan adalah Purposive Sampling. Purposive Sampling merupakan pengambilan sampel dengan pertimbangan tertentu (Sugiyono, 2018).

Penulis memilih perusahaan sebagai sampel dengan memilih perusahaan yang benar-benar memiliki kompetensi dengan topik penelitian. Berdasarkan pertimbangan atau kriteria yang dimaksud maka sampel terpilih 20 perusahaan sebagai sample dari 30 perusahaan manufaktur sub sektor makanan dan minuman yang terdaftar di Bursa Efek Indonesia tahun 2015-2019. Pengumpulan data dilakukan dengan studi perpustakaan (library research).

\section{HASIL DAN PEMBAHASAN}

\section{Uji Asumsi Klasik 1.1 Uji Normalitas}

Tujuan dari pengujian ini untuk mengukur apakah variabel yang diuji baik variabel bebas (independen) ataupun 
terikat (dependen) berdistribusi normal atau tidak karena model regresi yang baik adalah memiliki distribusi normal ataupun mendekati normal menurut (Imam Ghozali, 2018).

\section{Tabel 2. Hasil Uji Normalitas Data}

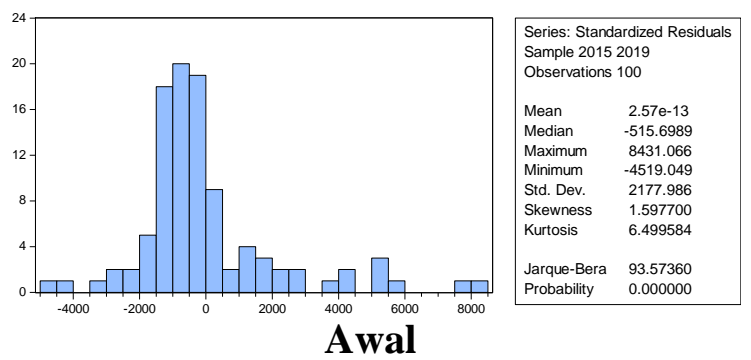

Sumber : Output Eviews 10

Berdasarkan hasil tabel 2 dapat dilihat bahwa nilai residual probability sebesar $0.000000<0,05$. Dengan demikian dapat disimpulkan bahwa $\mathrm{H}_{0}$ ditolak yang menyatakan data tidak berdistribusi normal.

Oleh sebab itu data awal perlu ditransformasikan kedalam bentuk Logaritma Natural (Ln). Kemudian data tersebut diolah kembali menggunakan Eviews. Maka diperoleh hasilnya adalah sebagai berikut :

\section{Tabel 3. Hasil Uiji Normalitas Setelah} Log Natural (Ln)

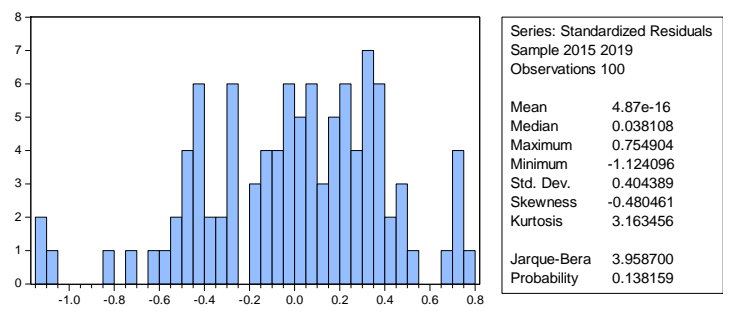

Sumber : Output Eviews 10

Setelah data dilakukan uji Logaritma Natural (Ln) pada tabel 3 dapat dilihat bahwa nilai residual probability sebesar $0.138159>0,05$. Dengan demikian dapat disimpulkan bahwa $\mathrm{H}_{0}$ diterima yang menyatakan data berdistribusi normal.
Menurut (Imam Ghozali, 2018) uji multikolonieritas bertujuan untuk menguji apakah model regresi ditemukan adanya korelasi antar variabel bebas (independen). Apabila tidak terjadi korelasi antara variabel bebas (independen) maka model regresi antara variabel bebas (independen) baik. Adapun hasil dari perhitungan multikolinieritas adalah sebagai berikut :

1. Return On Equity (ROE)

$$
\begin{aligned}
\mathrm{VIF} & =\frac{1}{1-R^{2}} \\
\mathrm{VIF} & =\frac{1}{1-0.572596} \\
\mathrm{VIF} & =\frac{1}{0.427404}=2.339707
\end{aligned}
$$

\section{Earning Per Share (EPS)}

$$
\begin{aligned}
& \mathrm{VIF}=\frac{1}{1-R^{2}} \\
& \mathrm{VIF}=\frac{1}{1-0.572596} \\
& \mathrm{VIF}=\frac{1}{0.427404}=2.339707
\end{aligned}
$$

Berdasarkan hasil dari perhitungan tersebut, maka nilai VIF yang disajikan pada tabel berikut ini :

Tabel 4. Hasil Uji Multikolinieritas

\begin{tabular}{|c|c|c|}
\hline Variabel & VIF & Kesimpulan \\
\hline $\begin{array}{c}\text { Return On } \\
\text { Equity } \\
\text { (X1) }\end{array}$ & 2,339707 & Tidak ada gejala \\
\hline $\begin{array}{c}\text { Earning } \\
\text { Per Share } \\
\text { (X2) }\end{array}$ & 2,339707 & Tidak ada gejala \\
\hline
\end{tabular}

Berdasarkan hasil dari Tabel 4 di atas dapat dilihat nilai VIF $<10$. Dengan demikian dapat disimpukan bahwa $\mathrm{H}_{0}$ diterima yang menyatakan tidak ada gejala multikolinieritas yang terjadi antara variabel independen.

\subsection{Uji Multikolinieritas}




\subsection{Uji Heterokesdastisitas}

Menurut (Imam Ghozali, 2018) bertujuan untuk melakukan pengujian apakah dalam model regresi, terjadi ketidaksamaan varians dari residual satu pengamatan ke pengamatan yang lainnya. Apabila terjadinya kesamaan varians dari residual satu pengamatan ke pengamatan yang lainnya disebut homokedastisitas.

Tabel 5. Hasil Uji Heteroskedastisitas

\begin{tabular}{|l|r|}
\hline Prob. F(2,97) & 0.0000 \\
\hline Prob. Chi-Square(2) & 0.0000 \\
\hline
\end{tabular}

Sumber: Output Eviews 10

Berdasarkam tabel 5 hasil pengujian heteroskedastisitas menghasilkan nilai Prob. Chi-Square sebesar $0.0000<0,05$. Dengan demikian dapat disimpulkan bahwa $\mathrm{H}_{1}$ diterima yang menyatakan terjadinya gejala heteroskedastisitas.

Oleh karena itu, untuk menyelesaikan gejala heteroskedastisitas ini maka perlu dilakukan peningkatan standar diferensiasi dari tingkat dasar menjadi tingkat 1 atau first different. Maka diperoleh hasilnya adalah sebagai berikut :

\section{Tabel 6. Hasil Uji Heteroskedastisitas Persamaan Diferensi}

\begin{tabular}{|l|l|}
\hline Prob. F(2,96) & 0.4905 \\
\hline Prob. Chi-Square(2) & 0.4823 \\
\hline
\end{tabular}

Sumber : Output Eviews 10

Berdasarkan tabel 6 hasil pengujian herekodastisitas menghasilkan nilai Prob. Chi-Square sebesar $0.4823>$ 0,05 . Dengan demikian dapat disimpulkan bahwa $\mathrm{H}_{0}$ diterima yang menyatakan tidak terjadinya gejala heteroskedastisitas.

\subsection{Uji Autokorelasi}

Menurut (Santoso, 2012) tujuan uji autokorelaso adalah untuk mengetahui apakah dalam sebuah model regresi linier ada korelasi antara kesalahan pengganggu pada periode $\mathrm{t}$ dengan kesalahan pada periode $\mathrm{t}-1$ (sebelumnya). Untuk melihat ada tidaknya autokolerasi dapat dilihat dari nilai dan statistic pada uji DurbinWitson (DW test) yang apabila nilai Durbin-Witson (DW) terletak diantara -2 sampai +2 berarti tidak terjadinya autokorelasi.

\section{Tabel 7. Hasil Uji Autokorelasi}

\begin{tabular}{|l|c|}
\hline Model & $\begin{array}{l}\text { Durbin- } \\
\text { Watson }\end{array}$ \\
\hline 1. Constant (X1,X2) & \multirow{2}{*}{0.777936} \\
\cline { 1 - 1 } $\begin{array}{l}\text { 2. Dependen Variabel } \\
\text { (Y) }\end{array}$ & \\
\hline
\end{tabular}

Sumber : Output Eviews 10

Berdasarkan hasil tabel 7 nilai Durbin-Witson (DW) sebesar 0.777936 . sehingga dapat ditarik kesimpulan bahwa tidak terjadinya autokorelasi dikarenakan nilai Durbin-Witson (DW) berada di antara -2 sampai +2 yaitu sebesar 0.777936 .

\section{Uji Hipotesis}

\subsection{Uji Analisis Regresi Berganda}

Menurut (Sugiyono, 2018) analisis regresi linear berganda digunakan oleh peneliti, apabila peneliti bermaksud meramalkan bagaimana keadaan (naik turunnya) variabel dependen, bila dua atau lebih variabel independen sebagai faktor prediktor (dinaik turunkan nilainya). Analisis regresi linear berganda merupakan hubungan secara linier antara dua atau lebih variabel bebas (independen) dengan variabel terikat (dependen). Model berganda dengan menggunakan (dua) variabel independen adalah sebagai berikut: 
Tabel 8. Hasil Uji Analisis Regresi Berganda

\begin{tabular}{|c|c|}
\hline Variabel & Coefficient \\
\hline $\mathrm{C}$ & 2.496766 \\
\hline $\mathrm{X} 1$ & -0.099223 \\
\hline $\mathrm{X} 2$ & 0.317648 \\
\hline
\end{tabular}

\begin{tabular}{|c|c|c|}
\hline Variabel & t-Statistic & Prob. \\
\hline C & 29.71446 & 0.0000 \\
\hline ROE & -1.699351 & 0.0932 \\
\hline EPS & 4.519922 & 0.0000 \\
\hline \multicolumn{3}{|c|}{ t Tabel $=\mathbf{t ~}(\boldsymbol{\alpha} / \mathbf{2} ; \mathbf{n}-\mathbf{k})$} \\
\hline \multicolumn{3}{|c|}{ t Tabel $=\mathrm{t}(0,025 ; 98)$} \\
\hline \multicolumn{3}{|c|}{1.98447} \\
\hline
\end{tabular}

Sumber : Output Eviews 10

Berdasarkan tabel 8 maka dapat disusun dengan persamaan sebagai berikut:

$$
\begin{gathered}
\boldsymbol{Y}=\boldsymbol{\alpha}+\boldsymbol{\beta}_{1} \boldsymbol{X}_{\mathbf{1}}+\boldsymbol{\beta}_{2} \boldsymbol{X}_{2}+\boldsymbol{e} \\
\mathrm{Y}=2.496766-0.099223+0.317648+\mathrm{e}
\end{gathered}
$$

Berdasarkan hasil analisis regresi data panel yang telah diuraikan maka dapat diinterprestasikan sebagai berikut :

ROE (X1) : Koefisien regresi Return On Equity sebesar - 0.099223

Nilai Return On Equity yang negatif menyatakan hubungan yang bersifat negatif terhadap harga saham yakni bahwa setiap penambahan ROE maka akan menurunkan harga saham.

EPS (X2) : Koefisien regresi Earning Per Share sebesar 0.317648

Nilai Earning Per Share yang positif menyatakan hubungan yang bersifat positif terhadap harga saham yakni bahwa setiap penambahan EPS maka akan meningkatkan harga saham.

\subsection{Uji Parsial (Uji t)}

Menurut (Imam Ghozali, 2018) uji statistik t pada dasarnya menunjukkan seberapa jauh pengaruh satu variabel penjelas atau independen secara individual dalam menerangkan variasi variabel dependen. Adapun hipotesis dari penelitian ini adalah sebagai berikut :

$\mathrm{H}_{0}$ : Variabel independen (Xi) tidak berpengaruh terhadap variabel dependen (Y) $; \mathrm{i}=1,2$

$\mathrm{H}_{1}$ : Variabel independen (Xi) berpengaruh terhadap variabel dependen (Y) $; \mathrm{i}=1,2$

Kriteria pengujian Tolak $\mathrm{H}_{0}$ jika nilai Sig. $<0,05$.

Tabel 9. Hasil Uji Parsial

Sumber : Output Eviews 10

Berdasarkan pada tabel 9 hasil uji parsial (uji t) maka dapat disimpulkan sebagai berikut :

\section{H1 : Pengaruh Return On Equity (ROE) terhadap Harga Saham}

Berdasarkan hasil uji parsial variabel $\mathrm{ROE}$ memiliki nilai $\mathrm{t}$ hitung sebesar -1.699351 yang lebih kecil dari nilai t tabel sebesar $1.98447(-1.699351<$ 1.98447) serta nilai signifikan ROE sebesar 0.0932 yang lebih besar dari 0.05 $(0.0932>0.05)$. Maka $\mathrm{H}_{0}$ diterima, sehingga dapat disimpulkan bahwa ROE tidak berpengaruh signifikan terhadap harga saham. Hasil tersebut didukung hasil penelitian sebelumnya yang dilakukan oleh (Nurlia, 2017) yang dalam penelitiannya menyatakan bahwa ROE tidak memiliki pengaruh terhadap harga saham.

\section{H2 : Pengaruh Earning Per Share (EPS) terhadap Harga Saham}

Berdasarkan hasil uji parsial variabel EPS memiliki nilai $t$ hitung sebesar 4.519922 yang lebih besar dari nilai t tabel sebesar 1.98447 (4.519922 > 1.98447) serta nilai signifikan EPS sebesar 0.0000 yang lebih kecil dari 0.05 $(0.0000<0.05)$. Maka $\mathrm{H}_{0}$ ditolak, sehingga dapat disimpulkan bahwa EPS berpengaruh signifikan terhadap harga saham. Hasil tersebut didukung hasil 
penelitian sebelumnya yang dilakukan oleh (Nurlia, 2017) dan (Pratama et al, 2019) yang dalam penelitiannya menyatakan bahwa EPS memiliki pengaruh terhadap harga saham.

\subsection{Uji Simultan (Uji F)}

Menurut Imam Ghozali (2018) uji F untuk mengetahui apakah ada pengaruh secara bersamaan antara variabel independen terhadap variabel dependen. Adapun hipotesisnya sebagai berikut :

H0 : Variabel independen (X) secara simultan tidak berpengaruh terhadap variabel dependen $(\mathrm{Y})$

H1 : Minimal ada satu Variabel independen (X) yang berpengaruh terhadap variabel dependenn (Y).

Maka dari itu kriteria pengujian Tolak H0 jika nilai Sig. $<0,05$.

\section{Tabel 10. Hasil Uji Simultan}

\begin{tabular}{|c|c|}
\hline F-Statistic & 376.3075 \\
\hline Prob(F-statistic) & 0.000000 \\
\hline F Tabel = F $(\mathrm{k} ; \mathrm{n}-\mathrm{k})$ & 3.09 \\
\cline { 1 - 1 } F Tabel = F $(2 ; 98)$ & \\
\hline
\end{tabular}

Sumber: Output Eviews 10

Berdasakran hasil dari tabel $10 \mathrm{di}$ atas menunjukkan bahwa $\mathrm{F}$ hitung sebesar 376.3075 lebih besar dari F tabel sebesar 3.09. Sedangkan, nilai signifikansinya 0.0000000 yang lebih kecil dari nilai 0,05. Makan $\mathrm{H}_{0}$ di tolak, sehingga dapat disimpulkan bahwa Return On Equity (ROE) dan Earning Per Share (EPS) secara simultan berpengaruh terhadap harga saham.

\subsection{Koefisien Determinasi $\left(\mathbf{R}^{2}\right)$}

Menurut (Imam Ghozali, 2018) koefisien determinasi $\left(\mathrm{R}^{2}\right)$ bertujuan untuk mengukur seberapa jauh kemampuan model dalam menerangkan variasi variabel dependen.

Tabel 11. Hasil Uji Koefisien Determinasi

\begin{tabular}{|l|l|}
\hline Adjusted R-squared & 0.987595 \\
\hline
\end{tabular}

Sumber : Output Eviews 10

Berdasarkan tabel 11 di atas diperoleh nilai Adjusted R-squared atau koefisien determinasi yang menunjukkan seberapa baik model regresi yang dibentuk oleh interaksi variabel independen dan variabel dependen. Nilai koefisien determinasi yang diperoleh sebesar 0.986710 yang dapat diartikan bahwa variabel independen (X) memiliki pengaruh kontribusi sebesar 98,67\% terhadap variabel dependen $(\mathrm{Y})$.

\section{SIMPULAN DAN SARAN 1. Simpulan}

Berdasarkan hasil analisis dan pembahasan yang telah dilakukan oleh penlitian, maka kesimpulan dari penelitian ini adalah sebagai berikut :

1. Return On Equity (ROE) tidak berpengaruh signifikan terhadap harga saham pada perusahaan manufaktur sub sektor makanan dan minuman yang terdaftar di Bursa Efek Indonesia Tahun 20152019.

2. Earning Per Share (EPS) berpengaruh signifikan terhadap harga saham pada perusahaan manufaktur sub sektor makanan dan minuman yang terdaftar di Bursa Efek Indonesia Tahun 20152019.

Return On Equity (ROE) dan Earning Per Share (EPS) secara simultan berpengaruh signifikan terhadap harga saham perusahaan manufaktur sub sektor 
makanan dan minuman yang terdaftar di Bursa Efek Indonesia Tahun 2015-2019.

\section{Saran}

Berdasarkan kesimpulan pada penelitian ini, maka dapat disampaikan beberapa saran sebagai berikut :

1. Berpengaruhnya Return On Equity (ROE) dan Earning Per Share (EPS) secara simultan terhadap harga saham perusahaan dapat dijadikan pertimbangan bagi perusahaan-perusahaan untuk meningkatkan kinerja fundamental perusahaan teritama yang berhubungan dengan rasio profitabilitas.

2. Bagi para investor hasil penelitian ini dapat digunakan sebagai bahan perimbangan terutama mengenai rasio keuangan khususnya untuk rasio profitabilitas seperti Return On Equity (ROE) dan Earning Per Share (EPS) dalam menanamkan modalnya ke perusahaan dan mengambil keputusan.

3. Bagi penelitian selanjutnya untuk lebih memperluas dan memperdalam analisis yang dilakukan, penelitian selanjutnya disarankan untuk mengambil periode yang lebih panjang.

4. Bagi peneliti selanjutnya sapat menambah variabel bebas (independen) karena masih banyak variabel lainnya yang dapat mempengaruhi harga saham.

\section{E. DAFTAR RUJUKAN}

Al Umar, A. U. A., \& Nur Savitri, A. S. (2020). Analisis Pengaruh ROA, ROE EPS Terhadap Harga Saham. Analisa Akuntansi Dan Perpajakan , 4, 30-36.

Abdul, H. (2005). Teori Keuangan dan Pasar Modal. Yogyakarta: EKONISIA.

Azis, M., Mintarti, S., \& Nadir, M. (2015). Manajemen Investasi: Fundamental,
Teknikal, Perilaku Investor dan Return Saham. Yogyakarta: Deepublish.

Audya, N., Sofia, M., \& Suprihartini, L. (2019). Faktor-faktor yang mempengaruhi harga saham pada perusahaan manufaktur yang tercatat pada bursa efek indonesia tahun 20152017. (1), 1-15.

Bursa Efek Indonesia, Laporan Keuangan Tahunan 2015, 2016, 2017, 2018 dan 2019 (diakses di http://www.idx.co.id/)

Egam, G. E. Y., Ilat, V., \& Sonny Pangerapan. (2017). Pengaruh Return On Asset (ROA), Return On Equity (ROE), Net Profit Margin (NPM) dan Earning Per Share (EPS) Terhadap Harga Saham Perusahaan Yang Tergabung Dalam Indeks LQ45 di Bursa Efek Indonesia Periode Tahun 2013-2015. Problems of a Mature Economy, 5(1), 45-61. https://doi.org/10.1007/978-1-34915400-5 6

Eugene, F. B., \& Joel, F. H. (2014). Dasardasar Manajemen Keuangan (14th ed.). Jakarta: Salemba Empat.

Imam Ghozali. (2018). Aplikasi Analisis Multivariate dengan Program IBM SPSS 25. Semarang: Badan Penerbit Universitas Diponegoro.

Indrawati, L., Darmayanti, N., \& Syakur, A. S. (2016). Pengaruh Earning Per Share (EPS), Return On Equity (ROE), Return On Assets (ROA) dan Net Profit Margin (NPM) terhadap Harga Saham. 251268.

Rahmadewi, P. W., \& Abundanti, N. (2018). Pengaruh EPS, PER, CR dan ROE Terhadap Harga Saham di Bursa Efek Indonesia. E-Jurnal Manajemen Unud7.

Singgih, S. (2012). Metode Regresi Data Panel. Yogyakarta: Ekosiana.

Sugiyono. (2018). Metode Penelitian Kuantitatif, Kualitatif dan $R \& D$. Bandung: Alfabeta.

Sutrisno. (2017). Manajemen Keuangan Teori Konsep \& Aplikasi (Edisi Kedua). Yogyakarta: EKONISIA.

Nurlia. (2017). Pengaruh Rasio Profitabilitas Terhadap Harga Saham Pada Perusahaan Rokok Yang Terdaftar 
Jurnal Ratri (Riset Akuntansi Tridinanti), Vol. 3, No. 1, hal. 73 - 84, Juli - Desember 2021 p-ISSN 2715 - 0208

di Bursa Efek Indonesia. Jurnal Sains Terapan, 2.

Pratama, C. A., Azizah, D. F., \& Ferina Nurlaily. (2019). Pengaruh Return On Equity (ROE), Earning Per Share (EPS), Current Ratio (CR), dan Debt to Equity Ratio (DER) Terhadap Harga Saham (Studi pada perusahaan Jakarta Islamic Index yang terdaftar di Bursa Efek Indonesia Tahun 2014-2017). Business Administration Journal, 66(1), 10-17. Retrieved from administrasibisnis.studentjournal.ub.ac.i d 